\title{
A comparative content analysis of South African and Kenyan drug policies from a social development perspective
}

\author{
L.S. Geyer, A. Lombard, G. Wairire
}

\begin{abstract}
South Africa and Kenya have both adopted a social development approach to shape their development agendas, as well as national policies in response to drug abuse. The goal of this study was to compare the content of South Africa’s National Drug Master Plan 2006-2011 (NDMP) and Kenya's National Drug Abuse Control Policy 2011 (NDACP) from a social development perspective. A quantitative comparative study was undertaken to compare the manifest content of these policies. A checklist of five dimensions of social development, with concomitant themes and indicators, was compiled for this purpose. Both policies emphasise the dimensions 'levels of service delivery' and 'integrated service delivery', while paying limited attention to the 'rights-based approach' and 'capital development' dimensions of social development. Lessons learnt from the study are presented in an effort to align drug policies, especially those of developing countries, with a social development approach.
\end{abstract}

Key words: content analysis, South Africa, Kenya, drug policy, social development indicators, National Drug Master Plan 2006-2011, National Drug Abuse Control Policy 2011, drug abuse 


\section{INTRODUCTION}

Drug abuse $^{1}$ (which in the context of this study refers to licit substances, such as alcohol and tobacco, as well as illicit substances, such as cannabis, heroin and nyaope) poses a serious threat to the achievement of sustainable human, social and economic development throughout the world (United Nations Office on Drugs and Crime [UNODC], 2013; World Health Organization [WHO], 2014). Drug abuse and the outflows thereof, such as drug-related crimes $^{2}$, necessitate the development and implementation of policies and programmes on the international, regional (e.g. Africa) and national level (e.g. South Africa \& Kenya). The first attempt by the United Nations to address drug abuse on the international level came about through the Single Convention on Narcotic Drugs, 1961 as amended in 1972 (United Nations [UN], 1972). This was followed by the Convention on Psychotropic Substances, 1971 (UN, 1971) and the United Nations Convention against Illicit Traffic in Narcotic Drugs and Psychotropic Substances, 1988 (UN, 1988). Unfortunately, these Conventions, which are premised on the belief that all countries should be drug-free, are not practical (Bewley-Taylor, 2003). Therefore, one attempt to strengthen international initiatives against drug abuse problems was the resolution entitled the Political Declaration and Plan of Action on International Cooperation towards an Integrated and Balanced Strategy to Counter the World Drug Problem, 2009 (UNODC, 2014).

Mashele (2005:1) purports that “[t]he drug problem has become a serious developmental challenge and continues to undermine collective and individual efforts of African government.” Drug abuse, combined with high levels of poverty, increases the vulnerability of the African continent to social problems such as crime and HIV and Aids (Lombard \&

\footnotetext{
1 This paper adopts the concept 'drug abuse' which could be considered a synonym for 'substance abuse'. Substance abuse “... refers to the misuse and abuse of legal substances such as nicotine, alcohol, over-the-counter drugs, prescribed drugs, alcohol concoctions, indigenous plants, solvents and inhalants, as well as the use of illicit drugs” (RSA, DSD, 2007:47).

${ }^{2}$ Drug-related crimes refer to illicit drug production and trafficking, drug cultivation, illicit drug trade, and crime offence such as the control of precursor chemicals and personal illicit drug use (UNODC, 2014).
} 
Wairire, 2010). The potential income of the drug industry draws many people living on the continent into illegal production and smuggling of, amongst others, cannabis, amphetaminetype stimulants (ATS) and heroin (UNODC, 2014, 2011). In reaction thereto the African continent established portfolio committees and protocols to manage the negative effects of drug abuse and drug-related crimes on the achievement of development goals (Mashele, 2005). The African Union (AU) established the Social Affairs Portfolio (Department of Foreign Affairs, 2004), while the Southern African Development Community (SADC) drafted a Protocol on Combating Illicit Drugs, 1996 and has initiated a Regional Drug Control Programme, 1998 (Franzern, 1999; Mashele, 2005). This protocol and programme are explicitly applicable to member states of the SADC, including South Africa. Furthermore, the East African Community, of which Kenya forms part, has established the EA Drug Information System, 2001 (Mashele, 2005).

As member states of the AU, both South Africa and Kenya ascribe to the goals of the New Partnership for Africa's Development (NEPAD), with one of the objectives being “To place African countries, both individually and collectively, on a path of sustainable growth and development” (RSA, Department of Foreign Affairs, 2004b). South Africa and Kenya have both adopted a social development approach to shape their development agendas. Both countries are signatories to the UN Summit for Social Development, 1995 and the Millennium Development Goals (MDGs), 2001. In this paper 'social development' is conceptualised as “... (1) an ultimate (end) goal of development activities; and (2) ... an appropriate approach to social welfare and thus an intervention strategy that incorporates social and economic processes to achieve social development as its ultimate goal” (Lombard, 2007:299). 
In response to drug abuse and its associated social problems, e.g. drug-related crimes, South Africa and Kenya have promulgated and adopted specific legislation and policies. Relevant for this paper is South Africa's National Drug Master Plan 2006-2011 (NDMP) (RSA, Department of Social Development [DSD], 2007) and Kenya’s National Drug Abuse Control Policy: Final Draft, 2011 (NDACP) (Government of the Republic of Kenya [GoK], Office of the President [OP], 2011).

Although both countries have adopted a social development approach, to date, no study has undertaken a comparative content analysis of African drug policy through the utilisation of social development indicators. This paper reports on a study to fill this research gap. Ulriksen (2010:25) affirms that "[comparative social policy research could] enlighten us on how social policy may serve both as an end and a means to social development without contradicting efforts of economic transformation". The guiding question for the study was: "Is a social development perspective entrenched in South Africa's NDMP 2006-2011 and Kenya's NDACP 2011, and if so, in what way?”

This paper firstly provides a synopsis of drug abuse trends in South African and Kenya. The next section gives an overview of the content of the NDMP and NDACP, respectively. Thereafter, the results of the analyses and a comparison of the content of the NDMP and NDACP are presented, followed by a discussion. The conclusions are presented as strengths and limitations of both the NDMP and NDACP, as considered from a social development perspective. Finally, lessons are identified for the development of drug policies on the African continent. 


\section{DRUG ABUSE TRENDS IN SOUTH AFRICA AND KENYA}

The 2012 Census estimates the South African population to be over 50 million. Alcohol is the dominant substance of abuse in South Africa and also results in the highest demand for treatment (RSA, DSD, 2010). Based on figures from 2010, South Africans fifteen years and older, predominantly consume beer (48.1\%), wine (17.8\%) and other alcohol concoctions (17.4\%) (WHO, 2014:297). Furthermore, for the same population it is estimated that 5.4\% suffers from alcohol use disorder, and 2.4\% from alcohol dependence (WHO, 2014:314). An estimated 270991 citizens are in need of treatment each year, although the country's treatment capacity is only about 21000 per year (RSA, DSD, 2010). Cannabis remains the most common drug of choice. Based on expert opinion the use of heroin and ATS are steadily increasing (UNODC, 2014). Statistics show some decrease in the use of crack cocaine (UNODC, 2014). Dada, Burnhams, Johnson, Parry, Bhana, Timol and Fourie (2014) reported that over-the-counter medicine and prescription medicine become a problematic issue, especially with regards to slimming tablets, analgesics and benzodiazepines. Nyaope (also called whoonga in some regions) is a concoction of heroin, cannabis, anti-retroviral medicine, rat poison, milk powder, bicarbonate of soda and pool cleaner, that continues to pose a great problem in especially three provinces of South Africa, namely Gauteng, Mpumalanga and Limpopo. Methamphetamine (also known as Tik) is used predominantly in the Western Cape (Dada et al., 2014). Amongst the greatest health risks associated with drug abuse is risky social behaviour and the concomitant increase in HIV infection of citizens and Aids-related deaths (Mashele, 2005), as well as the causal relationship between alcohol and infectious diseases, such as tuberculosis and pneumonia (WHO, 2014). The Global Burden on Disease Study (2010) confirmed that alcohol use remains the greatest risk factor for disease in the country (Institute for Health Metrics and Evaluation, 2010). 
As a case in point, between 2009 and 2010, 567 hectares of cannabis plantations (estimated value R397 million) were destroyed, and 165 drug couriers and 265 consignments of drugs were seized (estimated value R437 million) (RSA, DSD, 2010; UNODC, 2011). As a result of these figures, drug-related crimes place a huge burden on service providers and law enforcement agencies as the large scale of drug trafficking result in the breakdown of the social fabric of African countries, such as South Africa, and lead to social disorder (Mashele, 2005) which prevent the achievement of social development goals.

In 2011, the last Census, the Kenyan population was estimated to be over 42 million. Based on figures from 2010, Kenyans aged 15 and older, consume mostly beer (56.1\%) followed by spirits (21.6\%) and other alcohol concoctions (20.4\%) (WHO, 2014:297). It is further estimated that $3.1 \%$ of the the mentioned population suffers from alcohol use disorder, and 1.4\% from alcohol dependence (WHO, 2014:313). Miraa (khat) and bhang (a type of cannabis) are the drugs mostly abused by Kenyans (NACADA, 2012). In terms of law enforcement, heroin remains the drug most often seized in Kenya as the country is an attractive smuggling route to Europe (UNODC, 2014). The World Drug Report 2014 indicated that East Africa, which includes Kenya, is characterised by a growing instability in terms of drug-related crimes (UNODC, 2014)

Against this background, it is critical to design and implement policies that can curb the devastating impact of drug abuse on society.

\section{OVERVIEW OF THE NDMP AND NDACP}

Within the context of social development, and firmly rooted within a human rights ethos, it is imperative that both South Africa and Kenya mitigate the impact of drug abuse on dependent 
people, their significant others and the society at large, and curb other social ills, such as drug-related crimes. In South Africa the Constitution of the Republic of South Africa (1996), as the supreme law of the country, protects the fundamental human, social and economic rights of citizens as enshrined in the Bill of Rights (Patel, 2005). The National Development Plan 2030 (RSA, The Presidency, 2012), as a macro strategy, and the White Paper for Social Welfare (RSA, Ministry for Welfare and Population Development, 1997), a social welfare policy, create an enabling environment for social development practice in South Africa. At the time of this research, the country implemented its second drug policy, namely the National Drug Master Plan 2006-2011, with its vision of “... a drug-free society” (RSA, DSD, 2007:13).

Kenya, on the other hand, has enacted the Constitution of Kenya (2010), to protect the fundamental rights and freedoms of its citizens (GoK, 2010), while the Kenya Vision 2030 (GoK, 2007) shapes the country’s social development agenda. The National Drug Abuse Control Policy: Final Draft, 2011 represents the country’s drug policy with the vision of “... a healthy values-driven society free from alcohol and drug abuse” (GoK, OP, 2011:32).

\section{South Africa: $N D M P^{3}$}

The policy consists of six chapters outlining the policy directives.

Chapter 1, 'Introduction', contextualises, amongst others, different substances of abuse, a situational analysis of the drug problem in South Africa, the health and socio-economic consequences of drug abuse, and the national, African and global policy and legislation framework.

\footnotetext{
${ }^{3}$ The third NDMP of South Africa, NDMP 2013-2017, was adopted by the South African Parliament on 26 June 2013. However, the policy is not within the scope of the study reported on in this paper.
} 
The next chapter outlines the 'Framework for action' by focusing on aspects such as the policy's vision, mission and goals. The essence of the chapter is the demarcation of nine priority areas in the fight against drug abuse, namely crime, youth, other vulnerable groups (such as children living on the street, women, people with disabilities, older persons, and persons affected by HIV and Aids), community health, research and dissemination of information , international involvements, communication, capacity building and occupational groups at risk (for example, artists and musicians) (RSA, DSD, 2007).

In Chapter 3 the 'Strategic interventions', which are aimed at "actions that reduce the demand for drugs (prevention, treatment and rehabilitation)” (RSA, DSD, 2007:22), are outlined. According to Mabuza-Mokoko (2011), the strategic interventions that are specified in the NDMP are to be implemented according to an integrated strategy consisting of supply reduction (strategies to curb the supply of drugs), demand reduction (strategies to reduce the demand for drugs among the general public and those susceptible to addiction, and the reduction of conditions that lead to experimentation) and harm reduction (strategies to reduce the health, social and economic consequences caused by people who use drugs) in order to meet the requirements of the UNODC to which South Africa is a signatory (Bridge, Hunter, Atun, \& Lazarus, 2012; RSA, DSD, 2008). These strategies are explained with reference to different levels of service delivery, namely prevention, early intervention, treatment/ rehabilitation, and aftercare and reintegration services (RSA, DSD, 2007).

Efforts to manage drug abuse and curb the potential outflows thereof, require the collaboration of various key actors. Consequently, Chapter 4 outlines the 'Institutional framework', which refers to the roles and responsibilities of key actors in government, the 
business sector and civil society in mitigating drug abuse and eradicating associated social ills. Amongst other things, the chapter charts the key responsibilities of the Central Drug Authority (CDA), with its "primary function ... to monitor the implementation of the NDMP” (RSA, DSD, 2007:28). The mandates of different government departments, to contribute towards the achievement of the policy's vision, are also indicated.

Chapter 5, entitled 'Monitoring and evaluation', states that “[o]ngoing monitoring and evaluation are required to measure progress and achievements in respect of set objectives and the implementation of the NDMP by all stakeholders” (RSA, DSD, 2007:39). Monitoring and evaluation is the responsibility of the CDA, which consists of various stakeholders from government departments and NGOs who are appointed by the Minister of Social Development, in accordance with the Prevention and Treatment of Drug Dependency Act, 1992 (RSA, DSD, 2007).

Chapter 6, 'Conclusion', offers a summary of the policy with a statement of concern about the impact of drug abuse on the achievement of social development goals, namely "Solving South Africa's socioeconomic problems is an awesome task. In the long term, however, the failure to address [drug] abuse adequately could jeopardise the attainment of real reconstruction and development in South Africa.”

\section{Kenya: NDACP}

The NDACP was conceptualised to guide a coordinated multi-sectoral and multi-dimensional response to drug abuse in Kenya. This was upon recognition that drug abuse is not only a public health problem, but indeed a multi-sectoral and multi-dimensional problem that requires interventions from the different sectors in Kenya. 
Chapter 1, entitled 'Overview of alcohol and drug abuse', highlights, amongst others, the Kenyan government's recognition that drug abuse threatens both people's lives and national development. The chapter continues with an overview of global and national drug abuse trends. The broad intervention measures that the Kenyan government proposes to control drug use, particularly at the policy level, are also expounded in the chapter.

Chapter 2, 'Situational analysis', exhibits the alcohol and drug use situation in Kenya that has been made worse by drug cartels who use the country as a transit route for hard drugs, such as ATS and cocaine. The most commonly abused drugs and their socio-economic-political consequences are also outlined in this chapter. The NDACP indicates that families, education, health, and poverty and crime levels are negatively affected by drug use (GoK, OP, 2011). Consequently, interventions such as awareness creation about drugs, treatment and the broad challenges that affect implementation of interventions, are delineated in the chapter.

'Institutional responses' to drug abuse is the subject of the third chapter. As such, various UN conventions and treaties ratified by Kenya to deal with drugs are outlined. This is in addition to similar conventions agreed upon by African governments, as well as the broad legislative framework enacted by the Kenyan government to deal with drug abuse locally, for example, the Alcoholic Drinks Control Act, 2010. The institutional responses make reference to key role players in government, such as the National Agency for the Campaign Against Drug Abuse (NACADA), the Anti-Narcotics Unit, and line ministries, as well as non-state actors, for example the pharmaceutical industry, the media, education institutions, faith-based organisations, and community-based organisations (GoK, OP, 2011). 
Chapter 4, 'Vision, purpose, rationale, objectives \& guiding philosophy', offers a concise exposition of the vision, purpose, rationale and objectives of the NDACP. The overall purpose of the NDACP is "to provide a coordinated, effective and sustainable multi-sectoral and multi-dimensional framework to guide ADA management” (GoK, OP, 2011:32), while the overall objective is to enhance harmony, coordination and a clear mechanism for the management of drug use.

In Chapter 5, 'The National Drug Abuse Control Policy directions', the NDACP prioritises directions to attend to the threats that drug abuse poses to human lives and national development. The chapter further explains the key tenets which strengthen efforts to address drug abuse, including clear values, community participation, functional families and effective leadership (GoK, OP, 2011). In addition, the chapter outlines other key measures to deal with drug abuse, such as demand and supply reduction, workplace policies, and research for scientifically-based evidence that informs the policy direction and effective intervention programmes (GoK, OP, 2011).

Chapter 6, 'Monitoring and evaluation framework', concludes the NDACP, with the emphasis on the necessity of a sound monitoring and evaluation framework to track progress, efficiency and effectiveness in the implementation of the NDACP. As part of dissemination for advocacy and sensitisation, the chapter proposes that annual national and regional monitoring and evaluation forums for stakeholders need to be held. The chapter concludes with a strategic plan on how the policy needs to be reviewed every three years. 


\section{RESEARCH METHODS}

A quantitative research approach was adopted to compare the content of the NDMP and NDACP in order to determine objectively whether indicators of social development are encapsulated in the manifest content of the policies (Neuman, 2006). A comparative study was considered the most appropriate research design (Mouton, 2001). Mouton (2001) further indicates that comparative studies could be undertaken with textual data (as is the case in this study) with the purpose of comparing the units of analysis, namely the NDMP and NDACP.

To compare the content of the NDMP and NDACP from a social development perspective, the authors made use of a checklist (Delport \& Roestenburg, 2011). Because there was no previously developed or standardised checklist available, a specific procedure was followed to develop, to pilot test and to implement the designed checklist (compare Geyer, 2012). The checklist comprised of indicators which were derived from literature on social development and are hence embedded in the theoretical framework of social development (cf. Gray, 2002; Ife, 2001; Lombard, 2009, 2008, 2005, 2000; Midgley, 2010b, 1995; Midgley \& Tang, 2001; Patel, 2005; Patel \& Hochfeld, 2008; Sherraden, 2009). Babbie (2007) and Hong and Hodge (2009) concur that indicator development consists of at least three consecutive steps: (1) an in-depth analysis of the concept; (2) a literature review to isolate the themes (constructs) associated with each dimension; and (3) a delineation of every theme through the identification of features (attributes) which are ultimately individually operationally defined to serve as an indicator of the concept that is to be analysed. This study focused on the following five dimensions of social development (: (1) capital development; (2) an integrated service delivery strategy; (3) levels of service delivery; (4) mandate; and (5) a rights-based approach. 
The credibility of the checklist was ensured through both face and content validity (Krippendorff, 2004; Neuendorf, 2002). The reliability of the data collection instrument was determined through inter-coder agreement, as well as with the calculation of the correlation coefficient (r) (Krippendorff, 2004; Neuendorf, 2002). With $r=0.98$, the reliability of the checklist was confirmed (Pietersen \& Maree, 2007a). The content analysis process of Leedy and Ormrod (2005) was followed to analyse and compare the two policies. To comply with the required rigour of analysing manifest content, WordSmith Tools 6 was utilised during the comparative study. From the raw data, descriptive statistics, specifically frequencies, percentages, and mean scores, were calculated per dimension. Furthermore, to compare the dimensions in the two policies - with each dimension consisting of a limited number of indicators - Spearman's correlation coefficients $\left(r_{s}\right)$ were calculated (Pietersen \& Maree, 2007b). Microsoft Excel 2010 was used for all calculations, which were also verified by a statistician using SPSS 20.0.

\section{RESULTS}

The results are presented in three figures and two tables. Firstly, to provide a holistic overview of how the different dimensions are accounted for in the NDMP and NDACP, Figure 1 illustrates the mean scores per dimension. The subsequent figures (Figures 2 \& 3) and tables (Tables $1 \& 2$ ) offer details pertaining to the extent to which the social development indicators feature in the policy content.

\section{[Insert Figure 1: Means per dimension]}

The overall results reveal that South Africa and Kenya consider the social development perspective, and how it should be operationalised in drug policy, in a similar manner. The 
Pearson correlation coefficient, which was calculated to compare the two policies with reference to all five dimensions in totality, is $r=0.87$ and, as such, is considered a very strong association (Fouché \& Bartley, 2011). Through the comparative study (see Figure 1) it became clear that there were dimensions that have received considerable attention, while others were merely touched on. The two dimensions that received the most attention in the two policies, were levels of service delivery $(\mathrm{NDMP}=9.5$; NDACP $=5.75)$ and integrated service delivery strategy $(\mathrm{NDMP}=8.44$; NDACP $=3.33$ ). On the other side of the spectrum, the dimensions that were barely referred to in the policies, were a rights-based approach $(\mathrm{NDMP}=0.2 ; \mathrm{NDACP}=0)$ and capital development $(\mathrm{NDMP}=0.58 ; \mathrm{NDACP}=1.50)$. The dimension, mandate, was also addressed in policy content $(\mathrm{NDMP}=1.44$; NDACP $=1.11$, albeit to a limited extent. In the detailed analysis that follows the authors focus on the two dimensions which received the most and the least attention, respectively, followed by mandate as a dimension.

Figure 2 outlines the account of the social development indicators associated with levels of service delivery.

\section{[Insert Figure 2: Levels of service delivery]}

In this dimension the focus of analysis was on whether the policies made provision for different levels of services ranging from prevention, early intervention, rehabilitation/ institutionalisation and aftercare and reintegration services (RSA, DSD, 2007; GoK, OP, 2011). A strong correlation was found between the two policies $\left(r_{s}=0.63\right)$ with reference to this dimension. Rehabilitation received the most attention in both policies (NDMP $f=14$; 36.84\%; NDACP $f=9 ; 39.13 \%$ ), followed by prevention (NDMP $f=9 ; 23.68 \%$; NDACP $f=13$; 
$56.52 \%)$. Aftercare and reintegration services received attention in the NDMP ( $f=6 ; 15.79 \%)$, but was totally omitted in the NDACP.

The dimension that has received the second most attention in the policies' content was integrated service delivery strategy.

\section{[Insert Figure 3: Integrated service delivery strategy]}

With this dimension it was determined to what extent the policies made provision for harm and supply reduction strategies as prescribed by the UNODC. In this study harm reduction referred to "... a philosophy [that] emphasises the development of policies and programmes that focus directly on reducing the social, economic and health-related harm resulting from the use of alcohol or drugs" (RSA, DSD, 2007:46) and supply reduction to "[a] general term that refers to policies or programmes aimed [at] stopping the production and distribution of drugs, particularly law enforcement strategies for reducing the supply of illicit drugs” (RSA, DSD, 2007:47). The policies demonstrated a very strong correlation $\left(r_{\mathrm{s}}=0.77\right)$ with regards to this dimension. The detoxification and rehabilitation indicator had the highest frequency (NDMP $f=18 ; 23.68 \%$; NDACP $f=12 ; 40 \%$ ), followed by medical treatment (NDMP $f=1$; 1.32\%; NDACP $f=1$; 3.33\%). However, indicators such as substitution therapy and controlled access and distribution to drugs were not accounted for in either policy. Furthermore, two social development dimensions, namely a rights-based approach and capital development, received very little attention in the policies’ content.

This study aimed to determine whether the drug policies of these two countries, both with a history of human rights violations (Gray \& Lombard, 2008; Lombard \& Wairire, 2010), made 
provision for the human rights of people who are substance-dependent and are, amongst others, involved in drug-related crimes. The results revealed that, except for the NDMP, which referred to the Convention on the Rights of the Child, 1989 once, the drug policies failed to pay attention to this dimension. It was consequently impossible to calculate $r_{\mathrm{s}}$.

\section{[Insert Table 1: Capital development]}

Table 1 delineates capital development as a dimension of social development. The nexus of a social development perspective is the promotion of social and economic capital, together with human capital development (Lombard, 2005; Midgley \& Tang, 2001). With the aim of the study being to compare the content of the policies from a social development perspective, it was necessary to analyse and compare policy content with reference to capital development. The two policies presented with a very strong correlation $\left(r_{\mathrm{s}}=0.77\right)$ on this dimension. Economic capital development did not feature in the content of the NDMP, while the NDACP made provision for community economic development $(f=1 ; 5.56 \%)$ and social grants $(f=1$; 5.56\%). Both policies endorsed human capital development, specifically personal/ intrapersonal empowerment (NDMP $f=4 ; 57.14 \%$; NDACP $f=7 ; 38.89 \%$ ) and skills training (NDMP $f=2 ; 28.57 \%$; NDACP $f=4 ; 22.22 \%$ ). Social capital development was largely neglected in both policies, with reference to only community mobilisation and advocacy (NDMP $f=1 ; 14.29 \%$; NDACP $f=2 ; 11.11 \%$ ). However, the NDACP also referred to the promotion of solidarity $(f=3 ; 16.67 \%)$.

[Insert Table 2: Mandate] 
Service providers can only be expected to respond appropriately to drug abuse and its associated social ills, if they have a clear mandate to that effect. Table 2 indicates that, although the NDMP and NDACP both make provision for the international and African mandate of service providers to attend to drug abuse and drug-related crimes, the correlation between policies was weak $\left(r_{\mathrm{s}}=0.34\right)$. This could be ascribed to the fact that both policies failed to provide an unambiguous mandate for conventions and charters promoting a social development approach. With reference to the international mandate, only the NDACP $(f=2$; 20\%) referred to the MDGs, while neither policy contextualised the UN Summit for Social Development, 1995. Similar results were found with reference to the African mandate. Only the NDMP ( $f=1 ; 7.69 \%)$ accounted for NEPAD, while the NDACP failed to contextualise the initiative.

\section{DISCUSSION}

The comparison of the content of the two policies presents a very strong association. The presence or absence of social development indicators is largely mirrored in the content of the two policies.

If the policies' content is considered from a social development perspective, specifically with regards to levels of service delivery, it is a limitation that rehabilitation/ institutionalisation is emphasised, rather than prevention services. Rehabilitation is often associated with a residual welfare model, and not with social development (Lombard \& Kleijn, 2006). In accordance with a social development perspective, ideally the first line of service delivery should be prevention and early intervention services (compare RSA, DSD, 2006), in order to create an enabling environment for citizens to remain, or become, productive in the economy (Hall \& Midgley, 2004). Similarly, aftercare and reintegration services should form an essential 
component of the social service delivery framework in order to enable people to either become or remain active in the economy, after completion of treatment or following incarceration. It is therefore a limitation that this level of service delivery does not feature prominently in the policies. This finding might explain why aftercare and reintegration services are largely neglected in practice (compare Van der Westhuizen, Alpaslan, De Jager, 2011). For holistic service delivery, it is important that prevention and early intervention are emphasised in the policies, and complemented by rehabilitation and aftercare and reintegration services. Furthermore, the neglect of social service delivery on one or more levels could exacerbate existing drug abuse problems in both countries.

The level of detail in which the content of the two policies addresses harm and supply reduction strategies differ. Harm reduction strategies are closely related to a social development perspective because they promote the human rights of people involved with drug abuse or drug-related crimes (compare Barrett, 2012; Stevens, 2011). Wodak (2009:344) affirms that "any sensible drug policy will always combine elements of supply reduction, demand reduction and harm reduction”. Human rights in relation to drug abuse include the incorporation of strategies, such as substitution therapy for heroin dependence and needle syringe programmes, to prevent, for example, HIV transmission. The limited consideration given to harm reduction strategies is not in line with the core of the social development perspective, as it raises the question of whether the management of drug abuse and service delivery are focused on a human-rights approach. In contrast to the findings on harm reduction strategies, this study revealed that both policies make provision for numerous supply reduction strategies which have the potential to promote the realisation of social development goals, for example to prevent the production, manufacturing, sales and trafficking of drugs. In order to achieve social development outcomes, the authors posit that 
people should rather concentrate on skills development to realise human and economic capital that will enable them to become productive citizens that could secure individual sustainable livelihoods.

Seeing that the NDMP only refers to one international convention to promote the rights of children, and the NDACP fails to contextualise any human rights declaration or charter, the policies are clearly not aligned with a social development perspective in this regard. Social development is embedded in a human rights ethos (Patel, 2005). As both countries have constitutions founded on human rights (Lombard \& Wairire, 2010), it is important to acknowledge international and African treaties in the NDMP and NDACP to emphasise that the human rights of people who abuse substances, or are affected by alcohol and drug use, and/ or who have been involved in drug-related crimes, are indeed respected and protected by service providers when they are working with service users.

A unique feature of a social development perspective is its emphasis on the human, social and economic capital development of welfare users (Midgley, 2010a). Neither the NDMP nor the NDACP make clear provision for economic capital development. The economic capital development of service users with a drug abuse problem is important, as they often find it difficult to find employment after they have been discharged from a treatment centre. Drug policies need to provide an explicit mandate to service providers to attend to service users' economic capital development, otherwise the role that service providers in the field of addictions could play in the achievement of countries' social development outcomes is unclear. However, the policies primarily make provision for the human capital development of people affected by drug abuse. From the frequencies of the indicators related to human capital development, it is evident that service providers are informed about the necessity of 
investing time in, amongst other things, life skills training and building the self-esteem and self-reliance (Lombard, 2005) of people affected by drug abuse. The indicators pertaining to social capital development receive little attention, especially in the NDMP. Thin (2002) postulates that strong social capital in communities promotes the realisation of social development goals, while the absence of social capital amongst community members often results in increased drug use (McKee, 2002). Without a strong emphasis on social capital, both the NDMP and the NDACP reflect a gap in combating drug abuse and drug-related crime, which, in turn, impacts negatively on holistic service delivery.

From a social development perspective, the limited consideration given to the MDGs, and the absence of reference to the principal commitments adopted at the UN Summit for Social Development, 1995, are apparent. Both the principal commitments and the MDGs guide countries in the contextualisation and implementation of social development strategies in order to achieve social development goals (Midgley, 2010b; Singer, 2008). Likewise, the failure to acknowledge the role of NEPAD in promoting social development on the African continent is an oversight. In contrast to the limited focus on a social development mandate, both policies provide an unambiguous mandate to service providers in terms of international conventions and regional protocol in addressing drug abuse and drug-related crimes. The implication is that unless drug policies link social development and drug abuse, it is doubtful that service providers in the field of addictions will shape their services in ways that contribute towards the achievement of social development goals.

\section{CONCLUSIONS}

The conclusions of the content analysis of the NDMP and NCACP are presented as strengths and limitations of the respective policies from a social development perspective. 


\section{Strengths}

Although the policies accentuate rehabilitation/ institutionalisation, they do not exclude prevention of drug use and early intervention services to people who abuse drugs.

Both policies make provision for numerous supply reduction strategies in order to promote the realisation of a drug-free society.

The international and African mandates pertaining to drug use and drug-related crimes are adequately outlined in both policies.

\section{Limitations}

Prevention and early intervention are not prioritised in the content of the policies. On the contrary, rehabilitation received the most attention in policy content. In line with a social development perspective, prevention and early intervention services should be prioritised in drug policies.

Limited attention is given to harm reduction strategies. As such, the limitation of the policies is not the absence of harm reduction strategies, but the failure to give them equal weight alongside demand and supply reduction strategies.

The nexus of social development, namely equal consideration for both social and economic development, is not reflected in the content of either the NDMP or the NDACP. 
In the absence of specific international and regional commitments and treaties dealing with the protection of human rights, both policies fail to highlight the importance of human rights as an indicator of social development.

The policies do provide a clear mandate to service providers in the field of addictions, namely to simultaneously attend to the promotion of social development goals while also addressing the social problems associated with drug abuse.

\section{Lessons for the development of drug policies on the African continent}

This study presents lessons for South Africa and Kenya, which can be replicated in other African countries, to revise or draft drug policies to achieve an alignment with a social development perspective.

Prevention and early intervention must be prioritised as 'first line' levels of service delivery which are complemented by rehabilitation/ institutionalisation, as well as aftercare and reintegration services. This implies a shift in service delivery which needs to be apparent in the content of the policy.

Strategies pertaining to demand, supply and harm reduction should receive equal attention in drug policies.

Policies should, at least in the preamble, capture international treaties and declarations, African charters and initiatives, as well as national policies in order to provide the conceptual framework for a social development approach that underpins the policy directives. 
Drug policies should provide a clear mandate to service providers to fight drug abuse, and concomitant social ills, in accordance with a human rights ethos, and with specific reference to international, African and national conventions and charters dedicated to the promotion and protection of human rights.

It is recommended that the methodology that guided this study should be used by other countries to analyse their drug policies for alignment with a social development perspective. In addition, the outcomes of this study could be used to revise or draft drug policies in accordance to a social development perspective in order to achieve social development goals.

\section{REFERENCES}

Babbie, E. (2007). The practice of social research $\left(11^{\text {th }}\right.$ ed.) Belmont, CA: Thomson/Wadsworth.

Barrett, D. (2012). “A critique of human rights based approaches should demonstrate an understanding of human rights based approaches" International Journal of Drug Policy 23:185-186.

Bridge, J., Hunter, B.M., Atun, R. and Lazarus, J.V. (2012). "Global fund investments in harm reduction from 2002 to 2009” International Journal of Drug Policy 23:217-285.

Dada, S., Burnhams, N.H., Johnson, K., Parry, C., Bhana, A., Timol, F. and Fourie, D. (2014). "Alcohol and Drug Abuse Trends: January - June 2014 (Phase 36)", http://www.mrc.ac.za/adarg/sacendu.html (Accessed on 6/3/2015).

Delport, C.S.L. and Roestenburg, W.J.H. (2011). “Quantitative data-collection methods: Questionnaires, checklists, structured observation and structured interview schedules" in de Vos, A.S. (Ed.), Strydom, H., Fouché, C.B. and Delport, C.S.L. Research at grass roots for the social sciences and human service professions Pretoria: van Schaik Publishers, Fourth Edition, 171-205.

Fouché, C.B., \& Bartley, A. (2011). "Quantitative data analysis and interpretation” in de Vos, A.S. (Ed.), Strydom, H. Fouché, C.B. and Delport, C.S.L. Research at grass roots for the social sciences and human service professions Pretoria: van Schaik Publishers, Fourth Edition, 248-294. 
Geyer, L.S. (2012). A content analysis of the National Drug Master Plan 2006-2011 from a social development perspective (Unpublished Master's mini-dissertation). University of Pretoria, South Africa.

Gray, M. (2002). “Developmental social work: A 'strengths' praxis for social development” Social Development Issues 24(1):4-14.

Gray, M. and Lombard, A. (2008). "The post-1994 transformation of social work in South Africa” International Journal of Social Welfare 17:132-145.

Government of the Republic of Kenya. (2007). Kenya Vision 2030, A globally competitive and prosperous Kenya Ministry of State for Planning, National Development and Vision 2030. Nairobi: Kenya.

Government of the Republic of Kenya. (2010). Constitution of Kenya, 2010 Nairobi: Kenya. Kenya Gazette Supplement.

Government of the Republic of Kenya, Office of the President. (2011). National Drug Abuse Control Policy: Final Draft Nairobi: Kenya.

Hall, A. and Midgley, J. (2004). Social policy for development London: Sage Publications.

Hong, P.Y.P. and Hodge, D. (2009). "Understanding social justice in social work: A content analysis of course syllabi” Families in Society: The Journal of Contemporary Social Service 90(2):212-219.

Ife, J. (2001). Human rights and social work: Towards rights-based practice. London: Cambridge University Press.

Institute for Health Metrics and Evaluation. (2010). "Global Burden of Disease Study (2010)”, http://www.healthmetricsandevaluation.org (Accessed on 6/3/2015).

Krippendorff, K. (2004). Content analysis: An introduction to its methodology (2 ${ }^{\text {nd }}$ ed.) Thousand Oaks, CA: Sage Publications.

Leedy, P.D. and Ormrod, J.E. (2005). Practical research: Planning and design (8 ${ }^{\text {th }}$ ed.) Upper Saddle River, NJ: Pearson Education.

Lombard, A. (2009). "South Africa and Post-industrialism: Developmental Social Welfare A Policy Framework for Social Services with Children” in Powell, J.L. and Hendricks, J. (Eds). The Welfare State in Post-Industrial Society: A global perspective. London: Springer. 
Lombard, A. (2008). "The implementation of the White Paper for Social Welfare: A ten-year review” Social Work Practitioner-Researcher/Maatskaplikewerk Navorser-Praktisyn 20(2):154-173.

Lombard, A. (2005). "Impact of social services on human, social and economic development and the promotion of human rights in South Africa” Social Work 41(3):209-228.

Lombard, A. (2000). "Enhancing a human rights culture through social work practice and training” Social Work/Maatskaplike Werk 36(2):124-140.

Lombard, A. and Kleijn, W.C. (2006). "Statutory social services: An integrated part of developmental social welfare service delivery” Social Work 42(3/4):213-233.

Lombard, A. (2007). "The impact of social welfare services on social development in South Africa: An NGO perspective” Social Work 43(4):295-316.

Lombard, A. and Wairire, G. (2010). "Developmental social work in South Africa and Kenya: some lessons for Africa” Social Work Practitioner-Researcher, Special Issue, April 98-111.

Mabuza-Mokoko, E.A. (2011). Interview with the Social Work Manager, Central Drug Authority, National Department of Social Development, 3 February, Pretoria.

Mashele, P. (2005). "Mainstreaming drug control into socio-economic development in Africa” Institute for Security Studies Paper 100, March 1-8.

McKee, M. (2002). "Substance use and social and economic transition: The need for evidence” International Journal of Drug Policy 13:453-459.

Midgley, J. (2010a). "The theory and practice of developmental social work” in Midgley, J. and Conley. A. (Eds.). Social work and social development: Theories and skills for developmental social work New York, NY: Oxford University Press, 3-28.

Midgley, J. (2010b). “Community practice and developmental social work” in Midgley, J. and Conley, A. (Eds.). Social work and social development: Theories and skills for developmental social work New York, NY: Oxford University Press, 167-189.

Midgley, J. and Tang, K. (2001). "Social policy, economic growth and developmental welfare” International Journal of Social Welfare 10(4):244-252.

Mouton, J. (2001). How to succeed in your Master's \& Doctoral Studies: A South African guide and resource book Pretoria: van Schaik Publishers. 
National Authority for the Campaign Against Alcohol and Drug Abuse. (2012). Rapid situation assessment of the status of drug and substance abuse in Kenya, 2012 Nairobi: NACADA.

Neuendorf, K.A. (2002). The content analysis guidebook Thousand Oaks, CA: Sage Publications.

Neuman, W.L. (2006). Social research methods: Qualitative and quantitative approaches (6 $6^{\text {th }}$ ed.) Boston, MA: Allyn and Bacon.

Patel, L. (2005). Social welfare and social development in South Africa Cape Town: Oxford University Press Southern Africa.

Patel, L. and Hochfeld, T. (2008). "Indicators, barriers and strategies to accelerate the pace of change to developmental welfare in South Africa" Social Work PractitionerResearcher/Maatskaplikewerk Navorser-Praktisyn 20(2):192-211.

Pietersen, J. and Maree, K. (2007a). "Statistical analysis I: Descriptive statistics” in Maree, K. (Ed.). First steps in research Pretoria: van Schaik Publishers, 183-196.

Pietersen, J. and Maree, K. (2007b). “Overview of statistical techniques” in Maree, K. (Ed.). First steps in research Pretoria: van Schaik Publishers, 224-252.

Republic of South Africa. Department of Foreign Affairs. (2004a). "African Union in a nutshell”, http://www.dfa.gov.za/au.nepad/au_nutshell.htm (Accessed on 28/01/ 2008).

Republic of South Africa. Department of Foreign Affairs. (2004b). "NEPAD in brief”, http://www.dfa.gov.za/au.nepad/nepadbrief.htm (Accessed on 28/01/2008).

Republic of South Africa. Department of Social Development. (2006). Integrated Service Delivery Model towards improved social services RP31. Pretoria: Government Printers.

Republic of South Africa. Department of Social Development. (2007). National Drug Master Plan 2006-2011 RP05/2007. Pretoria: Government Printers.

Republic of South Africa. Department of Social Development. (2008). Central Drug Authority Annual Report for the year ended 31 March 2008 Pretoria: South Africa.

Republic of South Africa. Department of Social Development. (2010). Central Drug Authority Annual Report 2009/10 Pretoria: South Africa.

Republic of South Africa. Ministry for Welfare and Population Development. (1997). White Paper for Social Welfare, Notice 1108 of 1997 (Government Gazette, 386, no. 18166). Pretoria: Government Printers. 
Republic of South Africa. The Presidency. (2012). "National Development Plan 2030: Executive summary”, http://www.info.gov.za/issues/national-development-plan/index.html (Accessed on 4/9/2012).

Sherraden, M. (2009). Social Work, Global Poverty, and Development St. Louis: Centre for Social Development, Washington University at St Louis.

Singer, M. (2008). "Drugs and development: The global impact of drug use and trafficking on social and economic development” International Journal of Drug Policy 19:467-478.

Stevens, A. (2011). "Drug policy, harm and human rights: a rationalist approach" International Journal of Drug Policy 22:233-238.

Thin, N. (2002). Social progress and sustainable development Bloomfield, CT: Kumarian Press.

Ulriksen, M.S. (2010). “A review of comparative methods of social policy research in the Global South” Social Work Practitioner-Researcher, Special Issue, April 24-38.

United Nations Office on Drugs and Crime. (2011). World Drug Report 2011 Vienna: United Nations Publication.

United Nations Office on Drugs and Crime. (2014). World Drug Report 2014 Vienna: United Nations Publication.

Van der Westhuizen, M., Alpaslan, A. and De Jager, M. (2011). "Preventing relapses amongst chemically addicted adolescents: Exploring the state of current services" Social Work 47(3):350-370.

Wodak, A. (2009). "Harm reduction is now the mainstream global drug policy" Addiction 104:343-344.

World Health Organization. (2014). Global Status Report on Alcohol and Health 2014 Geneva: WHO Press. 
